\title{
Dimension of Management Control in Entrepreneurial University
}

\author{
Wirawan ED Radianto' ${ }^{1}$, Oscarius Yudhi Ari Wijaya ${ }^{2}$ \\ \{wirawan@ciputra.ac.id ${ }^{1}$, artaprima@gmail.com² \\ ${ }^{1}$ Universitas Ciputra, Indonesia \\ ${ }^{2}$ Akademi Sekretari dan Manajemen Indonesia (ASMI) Surabaya, Indonesia
}

\begin{abstract}
Abstrak. This study aims to investigate the dimensions of management control system from the lecturers point of view. This study explores how the control dimensions are able to motivate individuals. This study used a qualitative approach with phenomenology methods and case study strategies at universities with entrepreneurial characteristics. Data was collected through in-depth interviews and observations. The results show that there are several control dimensions that are able to influence behavior and motivate individual to work
\end{abstract}

Keywords: management control, control dimension, entrepreneurial university

\section{Background}

Management Control System (MCS) is very important since it ensures that human resources behave as expected by the organization [1]-[4]. MCS is able to motivate human resources so that they are able to increase operational effectiveness, support corporate strategy, enhance individual creativity, and enhance the capability of the company's capability to compete [5]-[10]. MCS is used to motivate human resource to act and can make decisions consistently with organizational goals.

This research investigates how lecturers interpret the management control dimensions that applied in the entrepreneurial universities. This study explains the relationship between the motivation of lecturers and the management control dimensions applied by university. This research is also able to reveal aspects that arise in the process of applying management control dimensions. The focus of this study is to explore the experience of actors in the application of management control.

The purpose of this study is to gain a deep understanding of the essence of management control from the perspective of the lecturer. This study focuses on the dimensions of management control. The next goal is to explore and describe how the control dimensions are able to motivate lecturers.

\section{Literature review}

Simons [2] suggests that MCS is a system and procedure that is formalized and used to maintain or change the pattern of organizational activities. According to Marginson [11] MCS is a control system that is used to influence human resource behavior in order to achieve organizational goals. Merchant and Stede [12] stated that MCS is a control system to ensure that human resources are managed in accordance with organizational goals. From these definitions, the authors conclude that MCS is related to human behavior. MCS always 
involves or relates to how to influence human behavior so that it relates to the motivational aspects of each individual.

Management control is the process of how managers ensure that organizational resources can be obtained and used effectively and efficiently in order to achieve organizational goals. Whereas according to Anthony and Govindarajan [13] management control is the process by which managers influence employees to implement organizational strategies.

\section{Method}

This research was built on the understanding that reality exists as a social product of human interaction and creatitvity [14]. The researcher views that management control is a social construction. MCS is formed to motivate individuals to have goals that are in accordance with the organization. Then the appropriate paradigm used in this study is the interpretive paradigm. The use of this paradigm provides a deeper understanding of the dimensions of management control from the perspective of the informant in its social context. Phenomenology as a methodology holds that the world must be explored so that it can be built intersubjective meaning [15], the world is one of the meanings that is constructed intersubjectively.

As a consequence, phenomenology as a research method does not recognize the hypothesis even though phenomenology can produce hypotheses that aim to be tested further. Phenomenology does not aim to thes the theory. Phenomenology does not begin with theory. In this case the interpretive paradigm and the qualitative approach tend to be used by phenomenology as its methodological basis.

In order to obtain comprehensive and in-depth analysis, the researcher uses a case study strategy, in this case the researcher uses a single case study strategy in entrepreneurial university. Data collection is done through observation and interviews and digging documents. Purposive sampling technique is used ini this study. The informants of this study were lecturers because lecturers were the main assets at the university and at the same time had the most important functions in the implementation of university education.

\section{Result and discussion}

This study successfully interviewed 21 informants from lecturers, foundation members, rectorates, deans, and heads of department. The process does not always run smoothly because of the busyness of the informants so that some schedules have to be repeated, there are even some who cannot be interviewed. However, all key informants were successfully interviewed. 


\subsection{Dimensions of Management Control}

This research found the dimensions of research control. We provide certain names for the control dimensions revealed in the field, namely the dimensions of social control, value control, competency control and preventive control.

\subsubsection{Social Control}

Social control includes how the relationship between the lecturer and his colleagues and the conditions of the work environment in which he works. A comfortable and conducive working environment will positively influence the behavior of the lecturers. Therefore, they will be motivated to work optimally and try to achieve organizational goals. The work environment that provides opportunities and allows lecturers to participate in planning and setting targets will motivate them to work according to what has been planned. It is also very important that there is intense discussion between lecturers and lecturers and lecturers with the leader, in other words there is a good relationship between individuals. This communication will create innovation, new initiatives, and creativity that had a positive impact on the university. This finding is relevant to the findings of several researchers [8]-[10], [16]. The interaction process turned out to be more able to motivate lecturers compared to formalized management controls.

\subsubsection{Value Control}

The researcher found that there were three values, namely the value of entrepreneurship, family values, and religious values. Family values make them very motivated to carry out the Tri Dharma of Higher Education and guide student projects. The existence of family values makes them feel comfortable in their work which has an impact on increasing the motivation of lecturers. The next value that arises is religious values.

The results of this study are relevant to several previous studies, namely the relationship between organizational culture or organizational values and management control [4], [13], [17]. This study was able to reveal how the process of organizational values related to management control even affects management control. More than that, this study succeeded in identifying any values that were able to motivate lecturers so that they behaved in accordance with what the university expected.

\subsubsection{Competence Control}

This study found that lecturers who are empowered to develop themselves will behave according to what is expected by the organization. Empowerment is not a reward, but a tool to motivate lecturers to work and excel. Lecturer development includes further study, participation in training, seminars, scholarships and coursework. The leadership's concern for understanding lecturers who always want to develop themselves will have an impact on the behavior of lecturers in order to behave according to what the university expects. Lecturers who are given the opportunity to develop themselves will behave differently with lecturers who have never developed their potential. 


\subsubsection{Preventive Control}

This control is like a "fence" which encloses every lecturer not to behave in a deviant manner. There are three aspects in this control system, the first aspect is that lecturers are prohibited from committing criminal acts such as corruption, manipulation and other frauds. Next is the lecturer must not violate the rules of the university. Some rules that they understand are not allowed to smoke in the campus environment, teaching hours are less than specified by the university, may not teach entrepreneurship courses, may not refuse assignments with unclear reasons, may not teach at other universities, may not arrive late and may not work anywhere else. These concepts aim to realize good governance at the university. While the last aspect is that lecturers must behave ethically. The ethical behavior that is often expressed by informants is to do plagiarism and uphold honesty.

\section{Conclusion}

Field research found that in fact not all formalized management controls were able to motivate lecturers. The researcher found that informal control plays an important role in motivating lecturers.

The informant interpreted the management control dimension as a tool aimed at assessing the performance of lecturers, improving the quality of the university, supporting the strategies implemented by the organization and developing the character of lecturers in an effort to realize good university governance. In order to achieve these objectives, there must be management control that is able to motivate lecturers so that they behave to achieve university goals.

Furthermore, the management control dimension that can motivate lecturers to behave according to what is expected by the university is social control, value control, competency control, and preventive control. Social-based control includes how to ensure that the university has a conducive work environment, good relational relations, and intensive communication between members of the organization. Value control will motivate individuals through organizational values. The values found are entrepreneurship values, family values, and religious values. Competency control motivates lecturers by increasing their competence and through the value of learning lecturers develop each other's knowledge with each other. Whereas Preventive Control is control that keeps lecturers so that they do not violate university rules, do not commit criminal acts and always behave ethically.

Interaction control plays a very important role in entrepreneurial universities. Through these controls the lecturer can give ideas and ideas to the leadership, in this case it will be able to motivate the lecturers to behave according to what is expected by the university. Ideas and ideas that will bring innovation and creativity are important parts of entrepreneurial university.

\section{References}

[1] E. G. Flamholtz, T. K. Das, and A. Tsui, "Toward an integrative framework of organizational control,” Accounting, Organ. Soc., vol. 10, pp. 35-50, 1985.

[2] R. Simons, Levers of Control. Boston: Harvard Business School Press, 1995.

[3] J. G. Birnberg, Some Reflections on The Evelution of Organizational Control. Behavioral Research in Accounting. 1998.

[4] W. Ouchi, "A conceptual framework for the design of organization control mechanisms," Manage. Sci., vol. 25, pp. 833-848, 1979.

[5] Kimura and Mourdoukourtas, "Effective Integration of Management Control Systems 
for Competing in Global Industries," Eur. Bus. Rev., vol. 12, no. 1, pp. 41-45, 2000.

[6] I. Herbert, "Business transformation through empowerment and the implications for management control systems," J. Hum. Resour. Costing Account., vol. 13, no. 3, pp. 221-244, 2009.

[7] J. F. Henri, "Management control systems and strategy: A resource-based perspective," Accounting, Organ. Soc., vol. 31, pp. 529-558, 2006.

[8] W. Wongkaew, "Management Accounting and Control Systems-Unnecessary Evils to Innovation?.," Chulalongkorn Bus. Rev., vol. 34, no. 3, pp. 1-21, 2013.

[9] T. Ismail, "Formatting Strategy and Management Control System: Evidence from Indonesia,” Int. J. Bus. Soc. Sci., vol. 4, no. 1, pp. 196-205, 2013.

[10] Z. Hoque and M. Chia., "Competitive forces and the levers of control framework in a manufacturing setting A tale of a multinational subsidiary," Qual. Res. Account. Manag., vol. 9, no. 2, pp. 123-145, 2012.

[11] D. E. W. Marginson, "Management control systems and their effects on strategy formation at middle-management levels: evidence from a U.K. organization," Strateg. Manag. J., vol. 23, no. 11, pp. 1019-1031, 2002.

[12] S. Merchant, Management Control Systems: Performance Measurement, Evaluation, and Incentives. 2nd edition. Prentice Hall, 2007.

[13] R. N. Anthony and V. Govindarajan, Management Control System 12th. New York: McGraw-Hill, 2007.

[14] G. Burrell and G. Morgan, Sociological Paradigms and Organizational Analysis: Elements of the Sociology of Corporate Life. London: heinemann Educational Books Ltd., 1979.

[15] A. Sobur, Filsafat Komunikasi: Tradisi dan Metode Fenomenologi. Bandung: PT Remaja Rosdakarya Bandung, 2013.

[16] A. Davila, G. Foster, and M. Li, "Reasons for management control systems adoption: Insights from product development systems choice by early-stage entrepreneurial companies," Accounting, Organ. Soc., vol. 34, pp. 322-347, 2009.

[17] R. Chenhall, "Management control system design within its organizational context: Findings from contingency-based research and directions for the future," Accounting, Organ. Soc., vol. 28, no. 2-3, pp. 127-168, 2003. 